\title{
Ion-Associated Complex of the Anionic Chelate of Germanium(IV) with Nitro Derivative of the Catechol and the Cation of Monotetrazolium Salt
}

\author{
Kirila Stojnova and Vanya Lekova ${ }^{*}$ \\ Department of General and Inorganic Chemistry with Methodology of Chemistry Education, Faculty of Chemistry, \\ Plovdiv University "Paisii Hilendarski", 24 Tsar Assen Street, Plovdiv 4000, Bulgaria \\ *Corresponding author: E-mail: vanlek@uni-plovdiv.bg \\ Tel.: +35932261420
}

Received: 11-21-2018

\begin{abstract}
The formation of an ion-associated complex between of the anionic chelate of germanium(IV) with 4-nitrocatechol (4NC) and the cation of 3-(2-naphtyl)-2,5-diphenyl-2H-tetrazolium chloride (TV) was investigated by spectrophotometry. The optimum conditions for the chelate formation and the extraction of the complex in the liquid-liquid extraction system $\mathrm{Ge}(\mathrm{IV})-4-\mathrm{NC}-\mathrm{TV}-\mathrm{H}_{2} \mathrm{O}-\mathrm{CHCl}_{3}$ were established. The validity of Beer's law was checked and some analytical characteristics were calculated. The association process in the aqueous phase and the extraction equilibria were studied and quantitatively characterized by the following key constants: association constant, distribution constant, extraction constant and recovery factor. The molar ratios of the components in the ion-associated complex were determined by independent methods. Based on this, a reaction scheme, a general formula and a structure of the ion-associated complex were suggested.
\end{abstract}

Keywords: Ge(IV); ion-associated complex; chelate formation; extraction equilibriums

\section{Introduction}

The germanium is a forth-period post-transition metal which forms complexes with various natural organic ligands, containing $\mathrm{O}, \mathrm{N}$ and $\mathrm{S}$ donor atoms, such as polyphenols and their functional derivatives, polyhydroxycarboxylic acids, aminopolyhydroxycarboxylic acids, thiopolycarboxylic acids, 8-hydroxyquinoline and its derivatives, aromatic derivates of hydroxyaldehydes and hydroxyketones, hydroxyazodyes. ${ }^{1-9}$ The colored anionic chelates of $\mathrm{Ge}(\mathrm{IV})$ form ion-associated complexes with bulky organic cations, like tetradecyl(trihexyl)phosphonium, methyltrioctylammonium, cetylpyridinium, cetyltrimethylammonium, tetraphenylammonium, tetraphenylarsonium. ${ }^{10-16}$

The structure and the properties of the tetrazolium salts determine their ability to form ion-associated complexes. ${ }^{17,18}$ The bulky hydrophobic organic substituents in the molecules of the tetrazolium salts increase the extractability of the ion-associated complexes. The presence of a quaternary nitrogen atom in the molecules of the tetrazolium salts determines the ability to form ionic associates with chelates of metals in aqueous phase without protonation, as opposed to the amines. The preparation and the application of ion-associated complexes of anionic chelates of metals with various natural organic and inorganic ligands containing $\mathrm{N}$ - or O-donor atoms and with the participation of mono- and ditetrazolium cations is a special scientific research field of chemistry of the coordination compounds. Tetrazolium salts are used as reagents for the preparation of various ion-associated complexes of metals, e.g. $\mathrm{Mo}(\mathrm{VI}), \mathrm{Ga}(\mathrm{III}), \mathrm{Co}(\mathrm{II}){ }^{19-26}$ The liquid-liquid extraction, as a part of the chemistry of the solutions and the coordination compounds, is applied to study the processes of complex formation and the extraction equilibria. The extraction spectrophotometry is a relatively simple, convenient, sensitive, selective, rapid to perform and inexpensive method for preparation and characterization of new complex compounds as well as for their application in the chemical analysis. ${ }^{27-32}$

The aim of this research was to study spectrophotometrically the formation of the ion-associated complex between the anionic chelate of germanium(IV) with 4-nitrocatechol (4-NC) and the cation of of 3-(2-naph- 
tyl)-2,5-diphenyl-2H-tetrazolium chloride (TV) in the liquid-liquid system $\mathrm{Ge}(\mathrm{IV})-4-\mathrm{NC}-\mathrm{TV}-\mathrm{H}_{2} \mathrm{O}-\mathrm{CHCl}_{3}$ as well as to evaluate the possible applications of the system for determination of traces of germanium(IV) in alloys, biological, medical and pharmaceutical samples.

\section{Experimental}

\section{1. Reagents and Apparatus}

$\mathrm{GeO}_{2}$ (Sigma-Aldrich, Munich, Germany, p.a.): A $2.0 \times 10^{-3} \mathrm{~mol} \mathrm{~L}^{-1}$ aqueous solution of $\mathrm{Ge}(\mathrm{IV})$ was prepared by dissolving $\mathrm{GeO}_{2}$ in water upon moderate heating.

4-Nitrocatechol (4-NC) (Sigma-Aldrich, p.a.): 4-NC was dissolved in distilled water to give a $1.0 \times 10^{-2} \mathrm{~mol} \mathrm{~L}^{-1}$ solution.

3-(2-Naphthyl)-2,5-diphenyl-2H-tetrazolium chloride (TV) (Fluka, p.a.): A chloroform $3.0 \times 10^{-3} \mathrm{~mol} \mathrm{~L}^{-1}$ solution was prepared.

The acidity of the aqueous medium was set using a buffer solution prepared by mixing $2.0 \mathrm{~mol} \mathrm{~L}^{-1}$ aqueous solutions of $\mathrm{CH}_{3} \mathrm{COOH}$ and $\mathrm{NH}_{4} \mathrm{OH}$.

The organic solvent $\mathrm{CHCl}_{3}$ was additionally distilled.

The $\mathrm{pH}$ was checked by HI $83140 \mathrm{pH}$ meter (Romania). A Camspec M508 spectrophotometer (United Kingdom), equipped with $10 \mathrm{~mm}$ path length cells, was employed for measurement of the absorbance.

\section{2. Procedure for Establishment of the Optimum Extraction- Spectrophotometric Conditions}

Aliquots of $\mathrm{Ge}(\mathrm{IV}), 4-\mathrm{NC}$, TV and buffer ( $\mathrm{pH}=3.5-$ 4.5) solutions were filled into separatory funnels. The resulting solutions were diluted with distilled water to a total volume of $10 \mathrm{~mL}$. Then $10 \mathrm{~mL}$ of chloroform was added and the funnels were shaken. A portion of the organic extract was filtered through a filter paper into a cell and the absorbance was measured against a blank sample. ${ }^{20,23}$

\section{3. Procedure for Determination of the Distribution Constant}

In order to determine the distribution constant $K_{D}$, it is necessary to measure the light absorbances $A_{1}$ and $A_{3}$, which are the light absorbance after a single extraction in chloroform under the optimum conditions for complex formation (Table 1, column 1) and after a triple extraction performed under the same conditions, respectively. The distribution constant $K_{D}$ can be calculated according to the ratio $K_{D}=A_{1} /\left(A_{3}-A_{1}\right)$. Single extraction: the single extraction is conducted with $10 \mathrm{~mL}$ of chloroform. After the separation of the two phases, the organic extract is transferred into a $25 \mathrm{~mL}$ calibrated flask which is brought to volume with chloroform. The measurement of the light absorbance $A_{1}$ is performed against a blank sample, pre- pared under the same conditions. Triple extraction: the first stage of the triple extraction is performed with $10 \mathrm{~mL}$ of chloroform and the extract is transferred into a $25 \mathrm{~mL}$ calibrated flask. During the second stage of the extraction, $8 \mathrm{~mL}$ of chloroform are added to the aqueous phase remaining after the first stage. The organic layer is added to that from the first stage. For the third stage of extraction, 7 $\mathrm{mL}$ of chloroform are added to the aqueous phase remaining after the second stage and an extraction is performed for the third time. The organic layer is transferred to the previous two. The calibrated flask is brought to volume with chloroform. The measurement of $A_{3}$ is performed against a blank sample prepared in the same way. ${ }^{22}$

\section{Results and Discussion}

\section{1. Optimum Extraction- Spectrophotometric Conditions}

\section{1. 1. Absorption Spectra}

The colored anionic chelate of germanium(IV)-4-NC can be efficiently extracted in chloroform in the presence of the bulky hydrophobic organic cations of monotetrazolium salt (TV). The absorption spectrum of the extract of the ion-associated complex, formed between the anionic chelate of $\mathrm{Ge}(\mathrm{IV})$ with $4-\mathrm{NC}$ and the cation of monotetrazoliun salt in $\mathrm{CHCl}_{3}$, is characterized by an absorption maximum in the visible range $\left(\lambda_{\max }=420 \mathrm{~nm}\right)$ (Figure 1 ).

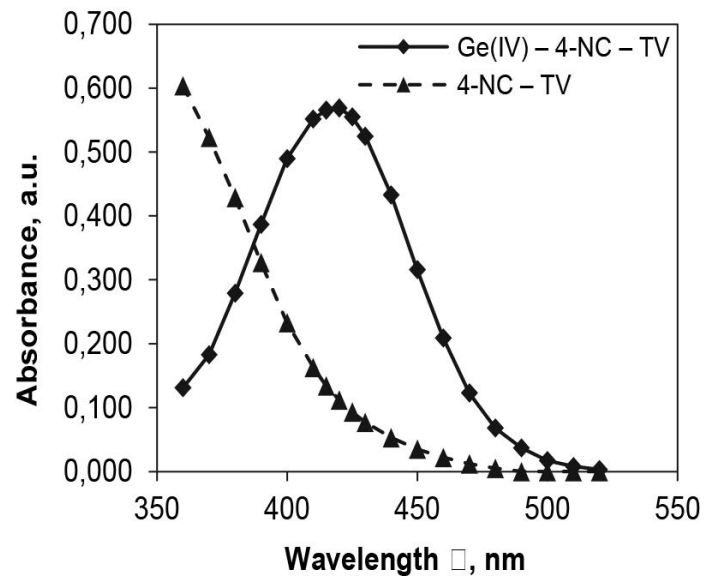

Figure 1. Absorption spectra of the complex Ge(IV)-4-NC-TV and of the blank sample 4 -NC-TV in $\mathrm{CHCl}_{3} ; C_{\mathrm{Ge}(\mathrm{IV})}=2.0 \times 10^{-5} \mathrm{~mol}$ $\mathrm{L}^{-1} ; C_{4-\mathrm{NC}}=5.0 \times 10^{-4} \mathrm{~mol} \mathrm{~L}^{-1} ; C_{\mathrm{TV}}=1.5 \times 10^{-4} \mathrm{~mol} \mathrm{~L}^{-1} ; \mathrm{pH}=4.0$; $\lambda=420 \mathrm{~nm} ; \tau=2 \mathrm{~min}$

\section{1. 2. Effect the Acidity of the Aqueous Phase and the Shaking Time}

The acidity of the aqueous phase has a substantial effect on the extraction of the anionic chelate Ge(IV)-4NC into the organic phase. The maximum and constant extraction of the ion-associated complex is achieved in 
the $\mathrm{pH}$ range from 3.5 to 4.5 (Figure 2). Acetate buffer solution with $\mathrm{pH}=4.0$ was used in all further experiments. The carried-out experiments, showed that the extraction equilibrium is achieved for shaking time of not less than $60 \mathrm{~s}$. The longer shaking time did not affect the absorbance. The further experiments were performed with shaking time $2 \mathrm{~min}$.

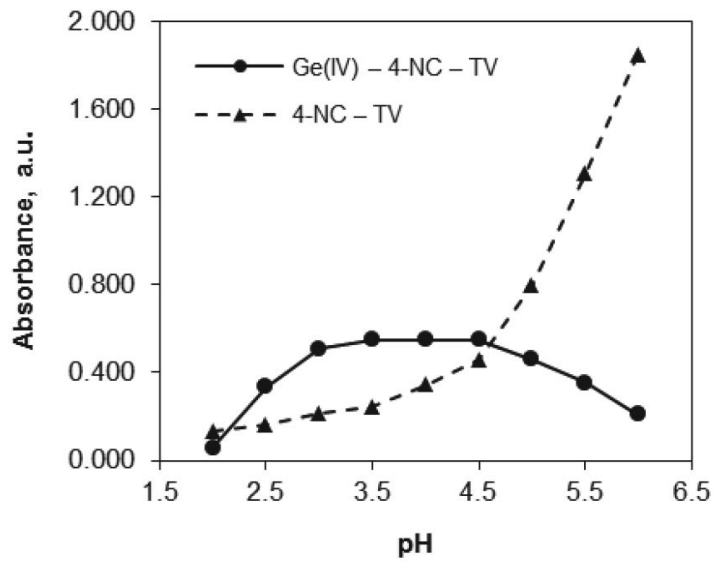

Figure 2. Absorbance of Ge(IV)-4-NC-TV extract against 4-NCTV extract and of 4-NC-TV against $\mathrm{CHCl}_{3}$ vs. $\mathrm{pH}$ of the aqueous phase; $C_{\mathrm{Ge}(\mathrm{IV})}=2.0 \times 10^{-5} \mathrm{~mol} \mathrm{~L}^{-1} ; C_{4-\mathrm{NC}}=5.0 \times 10^{-4} \mathrm{~mol} \mathrm{~L}^{-1} ; C_{\mathrm{TV}}=$ $1.5 \times 10^{-4} \mathrm{~mol} \mathrm{~L}^{-1} ; \lambda=420 \mathrm{~nm} ; \tau=2 \mathrm{~min}$

\section{1. 3. Effect of Reagents' Concentrations}

The concentrations of the reagents are the most important factor, influencing the extraction equilibrium. The chelate formation of $\mathrm{Ge}(\mathrm{IV})-4-\mathrm{NC}$ requires a 15.0 -fold excess of $4-\mathrm{NC}\left(\geq 3.0 \times 10^{-4} \mathrm{~mol} \mathrm{~L}^{-1}\right)$. For a maximum association and extraction the amount of TV should not be lower than a 4.5 -fold excess $\left(\geq 9.0 \times 10^{-5} \mathrm{~mol} \mathrm{~L}^{-1}\right)$.

\section{2. Beer's Law, Apparent Molar Absorptivity and other Analytical Characteristics}

The range of obedience to the Beer's law, i.e. the linear relationship between the germanium(IV) concentra- tion in the aqueous phase $\left(C_{\mathrm{Ge}(\mathrm{IV})}, \mu \mathrm{g} \mathrm{mL} \mathrm{mL}^{-1}\right)$ and the absorbance of the ion-association complex in the organic phase after extraction was studied using regression analysis under the optimum conditions for complex formation. The equation of a straight line was found to be $\mathrm{Y}=0.3933 \mathrm{X}+$ 0.0020 with a correlation coefficient squared 0.9995 . Under the optimum conditions for complex formation, the linearity is observed for concentrations up to $4.07 \mu \mathrm{g} \mathrm{cm}^{-3}$ $\mathrm{Ge}(\mathrm{IV})$. Further analytical characteristics, such as apparent molar absorptivity $\varepsilon^{\prime}$, adherence to Beer's law, Sandell's sensitivity, limit of detection and limit of quantification, are shown in Table 1, column 2.

\section{3. Molar Ratios of the Ion-Associated Complex}

The molar ratios of the ion-associated complex were determined by three independent methods: the mobile equilibrium method, the straight-line method of Asmus and the method of continuous variations. ${ }^{33}$

The mobile equilibrium method and the straightline method of Asmus were applied to prove the molar ratios $\mathrm{Ge}(\mathrm{IV}): 4-\mathrm{NC}$ and Ge(IV):TV. The values of the correlation coefficient squared $R^{2}$, determined by the straightline method of Asmus are presented in Table 2.

Table 2. Values of the correlation coefficient squared $\left(R^{2}\right)$, corresponding to various molar ratios of Ge(IV):4-NC and Ge(IV):TV (n and $\mathrm{m}$, respectively)

\begin{tabular}{|c|c|}
\hline \multicolumn{2}{|c|}{$\begin{array}{l}\text { Values of correlation coefficient squared }\left(R^{2}\right) \text {, } \\
\text { corresponding to molar ratios } 1,2 \text { and } 3 \text {, respectively }\end{array}$} \\
\hline Ge(IV):4-NC & Ge(IV):TV \\
\hline$(\mathrm{n}=1) R^{2}=0.9303$ & $(\mathrm{~m}=1) R^{2}=0.9841$ \\
\hline$(\mathrm{n}=2) R^{2}=0.9814$ & $(\mathrm{~m}=2) \mathrm{R}^{2}=0.9959$ \\
\hline$(\mathrm{n}=3) R^{2}=0.9988$ & $(\mathrm{~m}=3) R^{2}=0.9653$ \\
\hline
\end{tabular}

The results from the application of the straight-line method of Asmus and the mobile equilibrium method are shown in Figure 3 and Figure 4, respectively.

Table 1. Optimum extraction-spectrophotometric conditions and analytical characteristics of the system $\mathrm{Ge}(\mathrm{IV})-4-\mathrm{NC}-\mathrm{TV}-\mathrm{H}_{2} \mathrm{O}-\mathrm{CHCl}_{3}$

\begin{tabular}{ll}
\hline Optimum Conditions & Analytical Characteristic \\
\hline Absorption maximum $\left(\lambda_{\max }\right) 420 \mathrm{~nm}$ & $\begin{array}{l}\text { Apparent molar absorptivity }\left(\varepsilon^{\prime}\right) \\
(2.87 \pm 0.05) \times 10^{4} \mathrm{~L} \mathrm{~mol}^{-1} \mathrm{~cm}^{-1}\end{array}$ \\
Volume of the aqueous phase $10 \mathrm{~cm}^{3}$ & True molar absorptivity $(\varepsilon)$ \\
Volume of the organic phase $10 \mathrm{~cm}^{3}$ & $(2.95 \pm 0.01) \times 10^{4} \mathrm{~L} \mathrm{~mol}^{-1} \mathrm{~cm}^{-1}$ \\
pH of the aqueous phase $3.5 \div 4.5$ & Sandell's sensitivity (SS) $2.53 \mathrm{ng} \mathrm{cm}^{-2}$ \\
Shaking time $(\tau) 2 \mathrm{~min}$ & Adherence to Beer's law up to $4.07 \mu \mathrm{g} \mathrm{cm}^{-3}$ \\
Concentration of 4 -NC $\geq 3.0 \times 10^{-4} \mathrm{~mol} \mathrm{~L}^{-1}$ & Relative standard deviation (RSD) $1.98 \%$ \\
Concentration of TV $\geq 9.0 \times 10^{-5} \mathrm{~mol} \mathrm{~L}^{-1}$ & Limit of detection (LOD) $0.10 \mu \mathrm{g} \mathrm{cm}$ \\
\hline
\end{tabular}




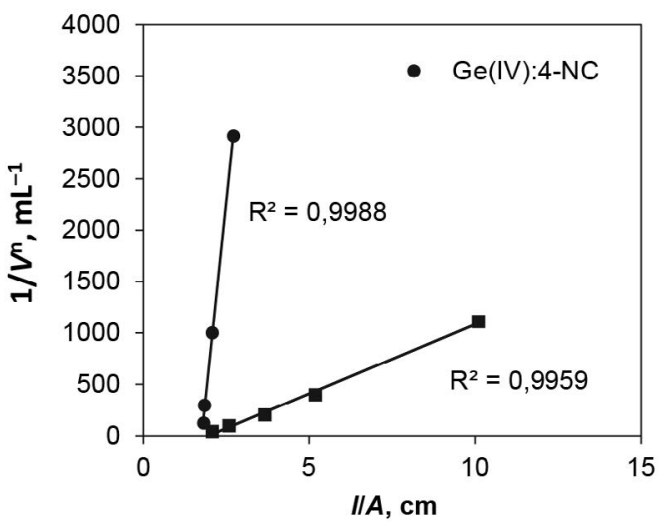

Figure 3. Determination of the molar ratios by the straight-line method of Asmus; $C_{\mathrm{Ge}(\mathrm{IV})}=2.0 \times 10^{-5} \mathrm{~mol} \mathrm{~L}^{-1} ; \mathrm{pH}=4.0 ; \lambda=420$ $\mathrm{nm} ; \tau=2 \mathrm{~min} ; \bullet \mathrm{Ge}(\mathrm{IV}): 4-\mathrm{NC}, C_{\mathrm{TV}}=3.0 \times 10^{-4} \mathrm{~mol} \mathrm{~L}^{-1}$, $\mathrm{Ge}(\mathrm{IV}): \mathrm{TV}, C_{4-\mathrm{NC}}=5.0 \times 10^{-4} \mathrm{~mol} \mathrm{~L}^{-1}$

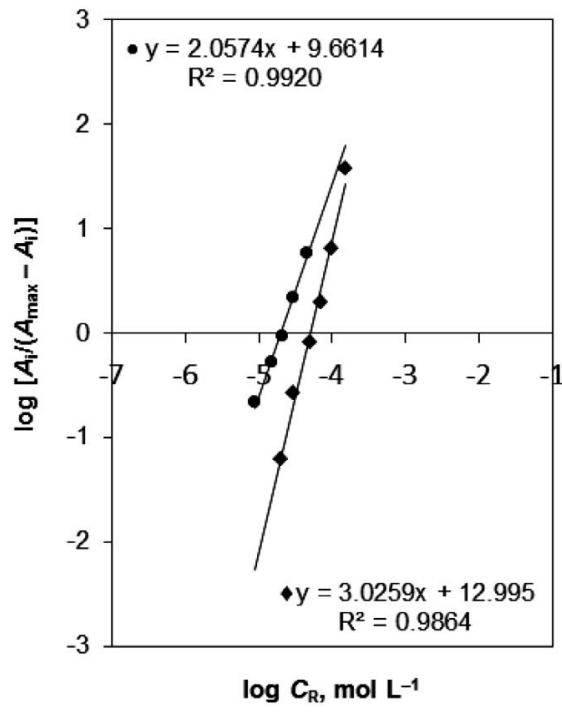

Figure 4. Straight lines by the mobile equilibrium method for determination of the molar ratios $\mathrm{Ge}(\mathrm{IV}): 4-\mathrm{NC}$ and $\mathrm{Ge}(\mathrm{IV}): \mathrm{TV} ; C_{\mathrm{Ge}(\mathrm{IV})}=$ $2.0 \times 10^{-5} \mathrm{~mol} \mathrm{~L}^{-1} ; \mathrm{pH}=4.0 ; \lambda=420 \mathrm{~nm} ; \tau=2 \mathrm{~min} ; \bullet \mathrm{Ge}(\mathrm{IV}): 4-\mathrm{NC}$, $C_{\mathrm{TV}}=3.0 \times 10^{-4} \mathrm{~mol} \mathrm{~L}^{-1} ; \bullet \mathrm{Ge}(\mathrm{IV}): \mathrm{TV}, C_{4-\mathrm{NC}}=5.0 \times 10^{-4} \mathrm{~mol} \mathrm{~L}^{-1}$

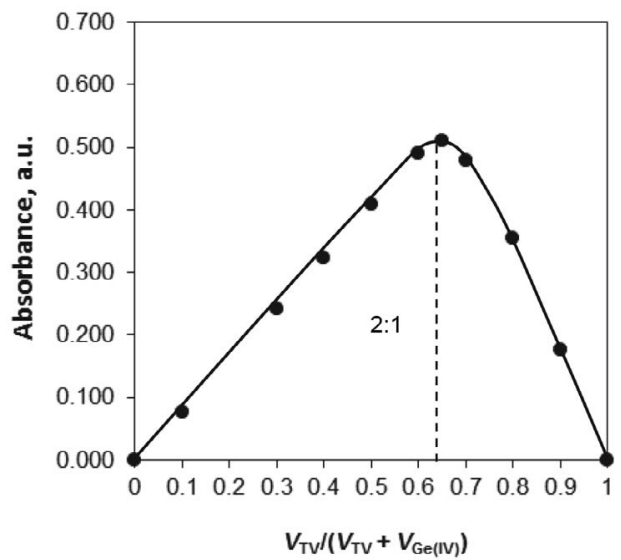

Figure 5. Determination of the molar ratio (n) Ge(IV):TV by the method of continuous variations; $C_{\mathrm{Ge}(\mathrm{IV})}+C_{\mathrm{TV}}=6.0 \times 10^{-5} \mathrm{~mol} \mathrm{~L}^{-1}$; $C_{4-\mathrm{NC}}=5.0 \times 10^{-4} \mathrm{~mol} \mathrm{~L}^{-1} ; \mathrm{pH}=4.0 ; \lambda=420 \mathrm{~nm} ; \tau=2 \mathrm{~min}$
On the basis of the results it can be concluded that $\mathrm{Ge}(\mathrm{IV}), 4-\mathrm{NC}$ and TV interact in molar ratio 1:3:2. The application of the method of continuous variations confirmed the molar ratio $\mathrm{Ge}(\mathrm{IV}): \mathrm{TV}=1: 2$ (Figure 5). ${ }^{33}$

\section{4. Reaction Scheme and Suggested General Formula}

Ions containing germanate $\left[\mathrm{Ge}(\mathrm{OH})_{6}\right]^{2-}$ are already described in the literature although in dilute aqueous solutions the major determined ions appear to be $\left[\mathrm{GeO}(\mathrm{OH})_{3}\right]^{-}$, $\left[\mathrm{GeO}_{2}(\mathrm{OH})_{2}\right]^{2-}$ and $\left\{\left[\mathrm{Ge}(\mathrm{OH})_{4}\right]_{8}(\mathrm{OH})_{3}\right\}^{3-} .{ }^{1}$ The performed experiments showed that the complex formation and the extraction of the ion-associated complex have occurred in the dilute solutions and the molar ratio established by the independent methods mentioned above was Ge(IV):4NC:TV $=1: 3: 2$. Therefore, the complex formation of anionic chelate Ge(IV)-4-NC can be given by equation (1):

$$
\begin{aligned}
& \left.\left[\mathrm{GeO}_{2}(\mathrm{OH})_{2}\right]^{2-}\right]_{\text {aq }}+3(\mathrm{HO})_{2} \mathrm{C}_{6} \mathrm{H}_{3}\left(\mathrm{NO}_{2}\right)_{\mathrm{aq}} \rightarrow \\
& \rightarrow\left\{\mathrm{Ge}\left[\mathrm{O}_{2} \mathrm{C}_{6} \mathrm{H}_{3}\left(\mathrm{NO}_{2}\right)\right]_{3}\right\}^{2-}{ }_{\mathrm{aq}}+4 \mathrm{H}_{2} \mathrm{O}
\end{aligned}
$$

Having in mind the molar ratio indicated above and the reaction of chelate formation of Ge(IV)-4-NC, it can be suggested that the formation of the ion-associated complex in the aqueous phase, its distribution between the aqueous and the organic phases and its extraction in chloroform can be given by the following equations (2-4).

$$
\begin{aligned}
& 2(\mathrm{TV})^{+}{ }_{\text {(aq) }}+\left\{\mathrm{Ge}_{2}\left[\mathrm{O}_{2} \mathrm{C}_{6} \mathrm{H}_{3}\left(\mathrm{NO}_{2}\right)\right]_{3}\right\}^{2-}{ }_{(\mathrm{aq})} \rightleftharpoons \\
& \rightleftharpoons(\mathrm{TV})_{2}\left\{\mathrm{Ge}\left[\mathrm{O}_{2} \mathrm{C}_{6} \mathrm{H}_{3}\left(\mathrm{NO}_{2}\right)\right]_{3}\right\}_{(\mathrm{aq})} \\
& (\mathrm{TV})_{2}\left\{\mathrm{Ge}\left[\mathrm{O}_{2} \mathrm{C}_{6} \mathrm{H}_{3}\left(\mathrm{NO}_{2}\right)\right]_{3}\right\}_{(\mathrm{aq})} \rightleftharpoons \\
& \rightleftharpoons(\mathrm{TV})_{2}\left\{\mathrm{Ge}\left[\mathrm{O}_{2} \mathrm{C}_{6} \mathrm{H}_{3}\left(\mathrm{NO}_{2}\right)\right]_{3}\right\}_{(\mathrm{org})} \\
& 2(\mathrm{TV})^{+}{ }_{(\mathrm{aq})}+\left\{\mathrm{Ge}\left[\mathrm{O}_{2} \mathrm{C}_{6} \mathrm{H}_{3}\left(\mathrm{NO}_{2}\right)\right]_{3}\right\}^{2-}{ }_{(\mathrm{aq})} \rightleftharpoons \\
& \rightleftharpoons(\mathrm{TV})_{2}\left\{\mathrm{Ge}\left[\mathrm{O}_{2} \mathrm{C}_{6} \mathrm{H}_{3}\left(\mathrm{NO}_{2}\right)\right]_{3}\right\}_{(\mathrm{org})}
\end{aligned}
$$

Therefore, the ion-associated anionic chelate of $\mathrm{Ge}(\mathrm{IV})-4-\mathrm{NC}$ with the cation of monotetrazolium salt can be represented by the general formula (TV $)_{2}\left\{\mathrm{Ge}_{\mathrm{C}}\left[\mathrm{O}_{2} \mathrm{C}_{6} \mathrm{H}_{3}\right.\right.$ $\left.\left.\left(\mathrm{NO}_{2}\right)\right]_{3}\right\}$.

\section{5. Equilibrium Constants, True Molar Absorptivity, Recovery Factor and Structure of the Ion-Associated Complex}

The association process in aqueous phase and the extraction equilibria were investigated and quantitatively characterized with respect to the following key constants: distribution constant $K_{D}$, association constant $\beta$, extraction constant $K_{e x}$ and recovery factor $R \%$.

The distribution constant $K_{D}$ was determined by equation (5), where $A_{1}$ and $A_{3}$ are the absorbances (measured against blanks) obtained after a single and triple extraction, respectively. 


$$
\begin{aligned}
& K_{D}=\left\{(\mathrm{TV})_{2}\left\{\mathrm{Ge}\left[\mathrm{O}_{2} \mathrm{C}_{6} \mathrm{H}_{3}\left(\mathrm{NO}_{2}\right)\right]_{3}\right\}\right\}_{(\mathrm{org})} / \\
& /\left\{(\mathrm{TV})_{2}\left\{\mathrm{Ge}\left[\mathrm{O}_{2} \mathrm{C}_{6} \mathrm{H}_{3}\left(\mathrm{NO}_{2}\right)\right]_{3}\right\}\right\}_{(\mathrm{aq})}= \\
& =A_{1} /\left(A_{3}-A_{1}\right)
\end{aligned}
$$
tion (6):

The recovery factor was determined from the equa-

$$
R \%=100 K_{D} /\left(K_{D}+1\right)
$$

The extraction constant $K_{e x}$ was calculated by two independent methods:

(i) from the equation $\log K_{e x}=\log K_{D}+\log \beta$

(ii) by the method of Likussar-Boltz. ${ }^{34}$

(i) The association constant $\beta$ was determined by two independent methods: Komar-Tolmachev method and Holme-Langmyhr method and their values are given in Table 3, column $2 .{ }^{33,34}$ The association constant $\beta$ was calculated by the method of Komar-Tolmachev from equation $(8) .^{33}$

$$
\beta=(\mathrm{l} / \mathrm{n})^{\mathrm{n}} /\left[\varepsilon(\operatorname{tg} \alpha)^{\mathrm{n}+1}\right]
$$

where $l$ is the cuvette thickness $(l=1 \mathrm{~cm}) ; \mathrm{n}$-the molar ratio between the components independently determined (e.g. by the mobile equilibrium method, the straight-line method of Asmus or the method of continuous variations) $(\mathrm{n}=2), \varepsilon$ - the true molar absorptivity.

The true molar absorptivity $\varepsilon$ was determined by the method of Komar-Tolmachev (Figure 6) from the equation of a straight line $\mathrm{Y}=0.4182 \mathrm{X}+3.3895(\varepsilon=1 /(\mathrm{b} \times$ $10^{-5}$ ) and its value is given in Table 1 , column $2 .{ }^{33}$

(ii) The method of Likussar-Boltz uses the data from the method of continuous variations (Figure 5). The extraction constant $K_{e x}$ was calculated by the equation of Likussar-Boltz for molar ratio 1:2 (equation 9): ${ }^{35}$

$$
\begin{aligned}
& \log K_{e x}=0,3522-2 \log K+ \\
& +\log Y_{\max }-3 \log \left(1-Y_{\max }\right)
\end{aligned}
$$

where $K$ is the total concentration of the reagents $(K=$

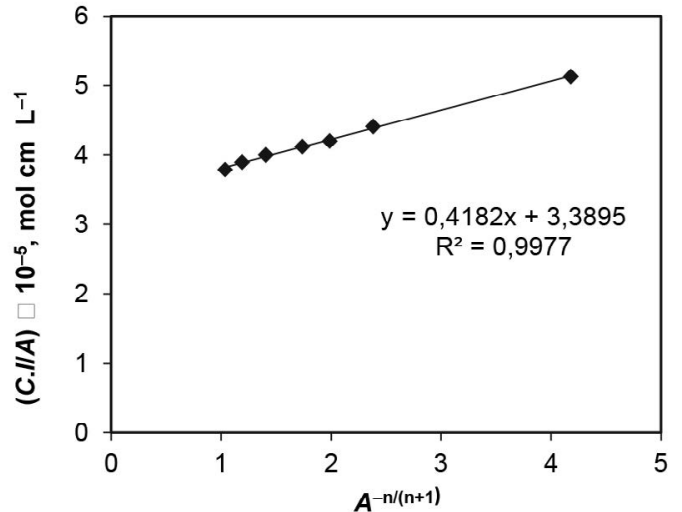

Figure 6. Dependency of $(C . l / A)$ on $A^{-\mathrm{n} /(\mathrm{n}+1)}$ (method of KomarTolmachev) $; C=C_{\mathrm{Ge}(\mathrm{IV})} \mathrm{mol} \mathrm{L}^{-1} ; C_{\mathrm{TV}}=2 C_{\mathrm{Ge}(\mathrm{IV})} \mathrm{mol} \mathrm{L}^{-1} ; C_{4-\mathrm{NC}}=$ $5.0 \times 10^{-4} \mathrm{~mol} \mathrm{~L}^{-1} ; \mathrm{pH}=4.0 ; \lambda=420 \mathrm{~nm} ; \tau=2 \mathrm{~min} ; A$ - absorbance; $l$ - cell thickness, $l=1 \mathrm{~cm} ; \mathrm{n}=2$

$\left.C_{\mathrm{Ge}(\mathrm{IV})}+C_{\mathrm{TV}}=6.0 \times 10^{-5} \mathrm{~mol} \mathrm{~L}^{-1}\right) ; \mathrm{Y}_{\max }$ and $\left(1-\mathrm{Y}_{\max }\right)$ are determined from the additionally plotted normalized absorption curve $\left(\mathrm{Y}_{\max }=0.900 ;\left(1-\mathrm{Y}_{\max }\right)=0.100\right)$.

The values of the equilibrium constants and the recovery factor, describing quantitatively the equilibrium in the aqueous phase and the extraction of the ion- associated complex in the organic phase are presented in Table 3 .

The results obtained by the independent methods are statistically similar and confirm the proposed scheme of the process of formation of the ion-associated complex in the aqueous phase, its distribution between the aqueous

\begin{tabular}{|c|c|}
\hline Equilibrium Constant and Recovery Factor & Value \\
\hline Equilibrium (equation 2) - Association constant $\beta$ & $\log \beta=(11.06 \pm 1.34)^{\mathrm{a}}$ \\
\hline $\begin{array}{l}\beta=(\mathrm{TV})_{2}\left\{\mathrm{Ge}\left[\mathrm{O}_{2} \mathrm{C}_{6} \mathrm{H}_{3}\left(\mathrm{NO}_{2}\right)\right]_{3}\right\}_{(\mathrm{aq})} /\left\{\left[(\mathrm{TV})^{+}\right]^{2}{ }_{\text {(aq })} \times\left\{\left\{\mathrm{Ge}\left[\mathrm{O}_{2} \mathrm{C}_{6} \mathrm{H}_{3}\left(\mathrm{NO}_{2}\right)\right]_{3}\right\}^{2-}\right\}_{(\mathrm{aq})}\right\} \\
\text { Equilibrium (equation 3) - Distribution constant } K_{D}\end{array}$ & \\
\hline$K_{D}=\left\{(\mathrm{TV})_{2}\left\{\mathrm{Ge}\left[\mathrm{O}_{2} \mathrm{C}_{6} \mathrm{H}_{3}\left(\mathrm{NO}_{2}\right)\right]_{3}\right\}\right\}_{(\text {org })} /\left\{(\mathrm{TV})_{2}\left\{\mathrm{Ge}_{D}\left[\mathrm{O}_{2} \mathrm{C}_{6} \mathrm{H}_{3}\left(\mathrm{NO}_{2}\right)\right]_{3}\right\}\right\}_{(\mathrm{aq})}$ & $\log K_{D}=(1.20 \pm 0.01)^{c}$ \\
\hline Equilibrium (equation 4) - Extraction constant $K_{e x}$ & $\log K_{e x}=(12.26 \pm 1.35)^{\mathrm{d}}$ \\
\hline$K_{e x}=\left\{(\mathrm{TV})_{2}\left\{\mathrm{Ge}_{2}\left[\mathrm{O}_{2} \mathrm{C}_{6} \mathrm{H}_{3}\left(\mathrm{NO}_{2}\right)\right]_{3}\right\}\right\}_{(\mathrm{org})} /\left\{\left\{[\mathrm{TV}]^{+}\right\}_{(\mathrm{aq})}^{2} \times\left\{\left\{\mathrm{Ge}\left[\mathrm{O}_{2} \mathrm{C}_{6} \mathrm{H}_{3}\left(\mathrm{NO}_{2}\right)\right]_{3}\right\}^{2-}\right\}_{(\mathrm{aq})}\right\}$ & $\log K_{e x}=(11.76 \pm 0.01)^{\mathrm{e}}$ \\
\hline Recovery factor $R \%$ & $R=(94.02 \pm 0.41) \%^{\mathrm{f}}$ \\
\hline
\end{tabular}
and the organic phases and its extraction in chloroform. Based on this, the proposed structure of the ion-associated complex is represented in Figure 7.

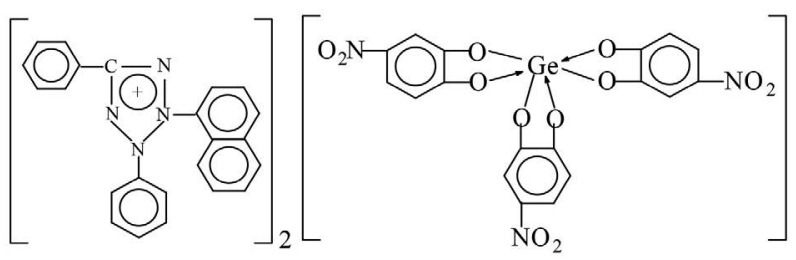

Figure 7. Structure of the ion-associated complex Ge(IV)-4-NC-TV

Table 3. Values of the Equilibrium Constants and the Recovery Factor

${ }^{a}$ Calculated by Komar-Tolmachev method (equation.(8)); ${ }^{\mathrm{b}}$ Calculated by Holme-Langmyhr method; ${ }^{34}{ }^{\mathrm{c}}$ Calculated by equation (5); ${ }^{\mathrm{d}}$ Calculated

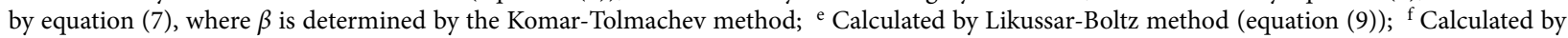
equation (6). 
and 4-nitrocatechol (4-NC) with the cation of of 3-(2-naphtyl)-2,5-diphenyl-2H-tetrazolium chloride (TV) was studied by spectrophotometry. The yellow-colored anionic chelate of Ge(IV)-4-NC interacted with the organic cation of the monotetazolium salt (TV) leading to the formation of an ion-associated complex well soluble in chloroform. The bulky organic molecule of TV determined the extractability of the ion-associated complex in organic phase. The optimum conditions for the association in the aqueous phase and for the extraction of the ion-associated complex Ge(IV)-4-NC-TV were established. The equilibrium constants and analytical characteristics needed for the quantitative assessment of the extraction equilibrium were calculated, i.e. the association constant $(\beta)$, the distribution constant $\left(K_{D}\right)$, the extraction constant $\left(K_{e x}\right)$, the recovery factor $(R)$, the apparent molar absorptivity $\left(\varepsilon^{\prime}\right)$, the true molar absorptivity $(\varepsilon)$, the limit of detection $(L O D)$, the limit of quantification $(L O Q)$ and the Sandell's sensitivity (SS). From the analytical characteristics of the extraction system $\mathrm{Ge}(\mathrm{IV})-4-\mathrm{NC}-\mathrm{TV}-\mathrm{H}_{2} \mathrm{O}-\mathrm{CHCl}_{3}$, it can be concluded that the ion-associated complex formed between the anionic chelate of $\mathrm{Ge}(\mathrm{IV})-4-\mathrm{NC}$ and the monotetrazolium cation could allow determinations of Ge(IV) in various samples with a high sensitivity. The molar ratio of the components, determined by independent methods, showed that the ion-associated complex could be represented with the general formula (TV) ${ }_{2}\left\{\mathrm{Ge}\left[\mathrm{O}_{2} \mathrm{C}_{6} \mathrm{H}_{3}(-\right.\right.$ $\left.\left.\left.\mathrm{NO}_{2}\right)\right]_{3}\right\}$. A corresponding reaction scheme of the complex formation and a structure of the ion-associated complex were also suggested.

\section{Acknowledgements}

The authors would like to thank the Research Fund of the University of Plovdiv for the financial support of the current research.

\section{References}

1. F. A. Cotton, G. Wilkinson, C. A. Murillo, M. Bochmann: Advanced Inorganic Chemistry, Wiley Publishers, New Jersey, 1999, pp. 392-394.

2. V. V. Skopenko, A. Y. Tsivadze, L. I. Sabranskiy, A. D. Garnovskiy: Coordination Chemistry, Akademkniga, Moscow, Russia, 2007, pp. 78-81.

3. V. S. Sergienko, L. K. Minacheva, A. V. Churakov, Rus. J. Inorg. Chem. 2010, 55, 2001-2030.

DOI:10.1134/S0036023610130012

4. W. Levason, G. Reid, W. Zhang, Coord. Chem. Rev. 2011, 255, 1319-1341. DOI:10.1016/j.ccr.2010.11.019

5. M. F. Davis, W. Levason, G. Reid, M. Webster, Dalton Trans. 2008, 17, 2261-2269. DOI:10.1039/b716765b

6. I. I. Seifullina, N. V. Shmatkova, E. E. Martsinko, Russ. J. Coord. Chem. 2010, 30, 214-220.
DOI:10.1023/B:RUCO.0000022120.49644.5c

7. F. Cheng, M. F. Davis, A. L. Hector, W. Levason, G. Reid, M. Webster, W. Zhang, Eur. J. Inorg. Chem. 2007, 2007, 24882495. DOI:10.1002/ejic.200700233

8. G. S. Pokrovski, F. Martin, J. L. Hazemann, J. Schott, Chem. Geol. 2000, 163, 151-165.

DOI:10.1016/S0009-2541(99)00102-3

9. D. Biller, C. Burschka, M. Penka, R. Tacke, Inorg. Chem. 2002, 41, 3901-3908. DOI:10.1021/ic0255757

10. V. A. Nazarenko: Analytical Chemistry of Germanuim, Nauka, Moscow, Russia, 1973, pp. 29-54.

11. I. I. Seifullina, A. G. Pesaroglo, L. Kh. Minacheva, E. E. Martsinko, V. S. Sergienko, Russ. J. Inorg. Chem. 2006, 51, $1892-$ 1899. DOI: $10.1134 /$ S0036023606120096

12. L. Zaijun, P. Jiaomai, T. Jan, Anal. Chim. Acta 2001, 445, 153159. DOI:10.1016/S0003-2670(01)01259-4

13. F. N. Shi, L. C. Silva, M. J. Hardie, T. Trindade, F. A. Paz, J. Rocha, Inorg. Chem. 2007, 46, 6502-6515.

DOI:10.1021/ic700507j

14. F. A. Torralvo, C. Fernandez-Pereira, M. C. Campanario, Ind. Eng. Chem. Res. 2010, 49, 4817-4823. DOI:10.1021/ie901020f

15. S. Jagatap, S. Kolekar, S. Han, M. Anuse, Inter. J. Anal. Bioanal. Chem. 2012, 2, 235-240. http://www.urpjournals.com

16. K. T. Mahmudov, R. A. Aliyeva, S. Z. Hamidov, F. M. Chyragov, S. R. Mardanova, M. N. Kopylovich, A. J. L. Pombeiro, Am. J. Anal. Chem. 2012, 3, 790-799.

DOI:10.4236/ajac.2012.312105

17. A. W. Nineham, Chem. Rev. 1955, 55, 355-483 DOI:10.1021/cr50002a004

18. H. Şenöz, Hacettepe J. Biol. Chem. 2012, 40, 293-301.

19. K. B. Gavazov, V. D. Lekova, G. I. Patrovov, Acta Chim. Slov. 2006, 53, 506-511.

20. V. Divarova, V. Lekova, P. Racheva, K. Stojnova, A. Dimitrov, Acta Chim. Slov. 2014, 61, 813-818.

21. K. Stojnova, V. Divarova, P. Racheva, G. Daskalov, V. Lekova, Monatsh. Chem. 2015, 146, 867-873.

DOI:10.1007/s00706-014-1402-7

22. V. Divarova, K. Stojnova, P. Racheva, V. Lekova, Acta Chim. Slov. 2016, 63, 97-103. DOI:10.17344/acsi.2015.1987

23. K. Stojnova, P. Racheva, V. Divarova, K. Bozhinova, V. Lekova, Acta Chim. Slov. 2016, 63, 654-660.

DOI:10.17344/acsi.2016.2513

24. K. Stojnova, P. Racheva, V. Divarova, K. Bozhinova, V. Lekova, Russ. J. Inorg. Chem. 2017, 62, 249-256.

DOI:10.1134/S0036023617020188

25. P. Racheva, K. Stojnova, V. Divarova, V. Lekova, Acta Chim. Slov. 2017, 64, 365-372. DOI:10.17344/acsi.2017.3214

26. K. Stojnova, V. Divarova, P. Racheva, K. Bozhinova, V. Lekova, Acta Chim. Slov. 2018, 65, 213-220.

DOI:10.17344/acsi.2017.3860

27. A. K. Babko, A. T. Pilipenko: Photometric Analysis, Khimiya, Moscow, Russia, 1968, pp. 159-164.

28. V. A. Mikhaylov: Extraction Chemistry, Nauka, Novosibirsk, Russia, 1984, pp. 194-249.

29. G. Kristian: Analytical Chemistry, BINOM, Moscow, Russia, 2009, pp. 414-426. 
30. Yu. A. Zolotov, V. A. Bodnya, A. N. Zagrusina, H. Freiser, Anal. Chem. 1982, 14, 93-174.

DOI:10.1080/10408348208085525

31. V. V. Divarova, K. T. Stojnova P. V. Racheva, V. D. Lekova, J. Appl. Spectrosc. 2017, 84, 231-236.

DOI:10.1007/s10812-017-0456-9

32. V. Divarova, K. Stojnova, P. Racheva, V. Lekova, Russ. J. Inorg. Chem. 2018, 63, 974-977. DOI:10.1134/S0036023618070057
33. M. I. Bulatov, I. P. Kalinkin: Practical Handbook on Photometric Methods of Analysis, Khimiya, Leningrad, Russia, 1986, pp. 174-264.

34. A. Holme, F. J. Langmyhr, Anal. Chim. Acta 1966, 36, 383-391. DOI:10.1016/0003-2670(66)80066-1

35. W. Likussar, D. F. Boltz, Anal. Chem 1971, 43, 1265-1272. DOI:10.1016/0003-2670(66)80066-1

\section{Povzetek}

S spektrofotometričnimi metodami smo raziskali tvorbo ionsko asociiranega kompleksa med anionskim kelatom germanija(IV) s 4-nitrokateholom (4-NC) in kationom iz 3-(2-naftil)-2,5-difenil-2H-tetrazolijevega klorida (TV). Določili smo optimalne pogoje za tvorbo kelata in za ekstrakcijo kompleksa v tekočina-tekočina ekstrakcijskem sistemu $\mathrm{Ge}(\mathrm{IV})-4-\mathrm{NC}-\mathrm{TV}-\mathrm{H}_{2} \mathrm{O}-\mathrm{CHCl}_{3}$. Preverili smo veljavnost Beerovega zakona ter izračunali nekatere analizne karakteristike. Asociacijski proces v vodni fazi in ekstrakcijsko ravnotežje smo proučili in kvantitativno karakterizirali sledeče ključne konstante: konstanto asociacije, porazdelitveno in ekstrakcijsko konstanto ter izkoristek ekstrakcije. Molsko razmerje komponent $\mathrm{v}$ ionsko asociiranem kompleksu smo določili na podlagi neodvisnih metod. Na podlagi dobljenih podatkov je predlagana reakcijska shema, splošna formula in struktura kompleksa. 